\title{
PENGARUH REPUTASI UNDERWRITER, PERSENTASE SAHAM YANG DITAWARKAN KE PUBLIK, DAN PENGGUNAAN DANA IPO UNTUK INVESTASI TERHADAP TINGKAT UNDERPRICING SAHAM SYARIAH PADA PERUSAHAAN YANG TERDAFTAR DI BEI TAHUN 2013-2016
}

\author{
Nur Afni Yunita ${ }^{1}$, Muftia Chairunnisa ${ }^{2}$ \\ ${ }^{1,2}$ Prodi Akuntansi Fakultas Ekonomi dan Bisnis Universitas Malikussaleh Lhokseumawe \\ nurafni.yunita@unimal.ac.id
}

\begin{abstract}
This study aims to examine the influence of underwriter reputation, the percentage of shares offered to the public and the use of IPO funds for investment to the level of underpricing of Islamic shares in companies conducting IPOs in 2013-2016. The sampling technique used is a purposive sampling in which the selection of samples based on certain criteria, so that the sample obtained in this study are 33 companies from a population of 342 companies. The dependent variable in this study is underpricing, while the independent variable is the underwriter's reputation, the percentage of shares offered to the public, and the use of IPO funds for investment. This study uses multiple regression analysis with hypothesis testing using SPSS 16 for Windows. The results show that the Underwriter reputation does not significantly influence the underpricing of sharia shares. The percentage of shares offered to the public does not significantly influence the underpricing of Islamic shares and the use of IPO funds for investment does not significantly influence the underpricing of Islamic shares.
\end{abstract}

Keywords: Underpricing, Underwriter Reputation, Percentage of Shares offered to the public, and Use of IPO funds for Investment.

\section{PENDAHULUAN}

Dalam proses go public, sebelum diperdagangkan di pasar sekunder, saham terlebih dahulu dijual di pasar primer atau sering disebut pasar perdana. Penawaran saham secara perdana ke publik melalui pasar perdana ini dikenal dengan istilah Initial Public Offering (IPO). Harga saham pada pasar perdana ditentukan oleh kesepakatan antara emiten (perusahaan penerbit) dengan underwriter (penjamin emisi), sedangkan harga saham pada pasar sekunder ditentukan oleh mekanisme pasar, yaitu permintaan dan penawaran. Menurut (Boubaker and Mezhoud, 2011), penetapan harga saham perdana suatu perusahaan adalah hal yang tidak mudah. Salah satu penyebab sulitnya menetapkan harga penawaran perdana adalah karena tidak adanya informasi harga yang relevan. Hal ini terjadi karena sebelum pelaksanaan penawaran perdana, saham perusahaan belum pernah diperdagangkan sehingga kesulitan untuk menilai dan menentukan harga yang wajar.

Sehingga emiten bekerjasama dengan underwriter untuk menetapkan kesepakatan harga saham perdana tersebut. Namun ternyata terdapat perbedaan kepentingan antara emiten dengan underwriter. Emiten sebagai pihak yang membutuhkan dana menginginkan agar harga saham perdananya tinggi dengan harapan emiten dapat memperoleh dana sebesar yang diharapkan dan secara otomatis dapat merealisasikan proyek ekspansi yang akan dilakukan. Namun tidak demikian halnya dengan underwriter yang berusaha untuk meminimalkan resiko penjaminan yang menjadi tanggung jawabnya dengan menentukan harga yang lebih dapat diterima oleh para investor di pasar modal dengan harapan semua saham perdana yang ditawarkan dapat terjual (Handayani, 2008). Sehingga tidak ada kewajiban bagi underwriter untuk membeli saham yang 
ternyata tidak laku terjual dengan harga yang sama jawab penjaminannya. dengan harga IPO sebagai bentuk dari tanggung

Beberapa Perusahaan syariah yang mengalami Underpricing pada saat penawaran perdana tampak seperti tabel 1 berikut :

Tabel 1

Daftar perusahaan syariah yang mengalami underpricing pada saat IPO

Selama periode 2013-2016

\begin{tabular}{|c|c|c|c|c|c|c|}
\hline No & Kode & $\begin{array}{c}\text { Nama } \\
\text { Perusahaan }\end{array}$ & $\begin{array}{c}\text { Tingkat } \\
\text { Under } \\
\text { pricing } \\
(\%)\end{array}$ & Underwriter & $\begin{array}{c}\text { Persentase } \\
\text { Saham yang } \\
\text { di tawarkan } \\
\text { ke publik } \\
(\%)\end{array}$ & $\begin{array}{l}\text { Pengguna } \\
\text { an dana } \\
\text { IPO untuk } \\
\text { invesatsi }\end{array}$ \\
\hline 1 & CINT & $\begin{array}{l}\text { PT Chitose } \\
\text { Internasional } \\
\text { Tbk. }\end{array}$ & 2,12 & $\begin{array}{l}\text { PT Dana Reksa } \\
\text { Sekuritas } \\
\text { PT Sinarmas } \\
\text { Sekuritas }\end{array}$ & 30,00 & $10 \%$ \\
\hline 2 & BALI & $\begin{array}{l}\text { PT Bali } \\
\text { Towerindo } \\
\text { Sentra Tbk. }\end{array}$ & 50 & $\begin{array}{l}\text { RHB OSK } \\
\text { Sekuritas }\end{array}$ & 87,16 & $0 \%$ \\
\hline 3 & BIRD & $\begin{array}{l}\text { PT Blue Bird } \\
\text { Tbk. }\end{array}$ & 14,62 & $\begin{array}{l}\text { PT Suisse } \\
\text { Sekuritas } \\
\text { Indonesia }\end{array}$ & 15,05 & $28,58 \%$ \\
\hline 4 & CANI & $\begin{array}{l}\text { PT Capitol } \\
\text { Nusantara } \\
\text { Indonesia Tbk. }\end{array}$ & 19,50 & $\begin{array}{l}\text { PT Trimegah } \\
\text { Sekuritas }\end{array}$ & 12,5 & $100 \%$ \\
\hline 6 & BLTZ & $\begin{array}{l}\text { PT Graha Layar } \\
\text { Prima Tbk. }\end{array}$ & 13,33 & $\begin{array}{l}\text { PT Indo Premire } \\
\text { Sekuritas }\end{array}$ & 22,04 & $100 \%$ \\
\hline 7 & LINK & $\begin{array}{l}\text { PT Link Net } \\
\text { Tbk. }\end{array}$ & 50 & $\begin{array}{l}\text { PT Ciptadana } \\
\text { Sekuritas }\end{array}$ & 19,93 & $0 \%$ \\
\hline 8 & MDIA & $\begin{array}{l}\text { PT Intermedia } \\
\text { Capital Tbk. }\end{array}$ & 9,42 & $\begin{array}{l}\text { PT Ciptadana } \\
\text { Sekuritas }\end{array}$ & 10,00 & $80 \%$ \\
\hline
\end{tabular}

Sumber : Data Diolah Penulis 2017

Underwriter memiliki informasi yang lebih baik tentang pasar modal, sedangkan pihak emiten merupakan pihak yang tidak memiliki informasi tentang pasar modal sehingga apabila di antara mereka tidak memiliki informasi yang lengkap maka akan terjadi perbedaan harga.

Underpricing juga dipengaruhi oleh faktor lain seperti Persentase penawaran kepada publik. Persentase penawaran kepada publik menunjukkan porsi kepemilikan saham yang dikuasai oleh publik. Ljungqvist (2000) menyatakan bahwa kepedulian pemilik perusahaan terhadap underpricing diukur dari berapa banyak saham yang dijual pada saat IPO. Yong (2009) menyatakan bahwa persentase penawaran kepada publik dapat dijadikan indikator untuk melihat aktivitas investor di pasar sekunder, karena persentase penawaran berhubungan dengan kegiatan spekulatif dari investor.

Informasi yang terdapat dalam prospektus salah satunya adalah informasi mengenai penggunaan 
dana IPO yang dijelaskan secara presentase dari rencana kegiatan yang akan dilakukan oleh emiten, yang salah satunya adalah rencana penggunaan dana IPO untuk investasi. Informasi tentang spesifikasi rencana penggunaan dana hasil IPO berhubungan dengan keputusan investasi para investor di pasar modal. Variabel penggunaan dana IPO untuk investasi diukur dengan presentase dana investasi IPO (Kim, 1993 dalam Aini, 2013).

Penelitian Trisnaningsih (2005) dan Sandhiaji (2004) menyatakan bahwa variabel reputasi underwriter berpengaruh signifikan terhadap underpricing. Namun hasil penelitian tersebut inkonsisten dengan penelitian yang dilakukan oleh Suyatmin (2006) yang menyatakan bahwa variabel reputasi underwriter tidak berpengaruh signifikan terhadap underpricing.

Penelitian Suyatmin (2006) menyatakan bahwa reputasi auditor berpengaruh signifikan terhadap underpricing. Namun hasil penelitian tersebut inkonsisten dengan penelitian yang dilakukan oleh Sandhiaji (2004) yang menyatakan bahwa reputasi auditor tidak berpengaruh terhadap underpricing.

\section{LANDASAN TEORI}

\section{Initial Public Offering (IPO)}

Menurut Brealy (2007:414), Penawaran Publik Awal (IPO) adalah penawaran saham pertama kepada publik secara umum. Penjualan saham pertama ini dikenal sebagai Initial Public Offering (IPO). Perusahaan dikatakan go public ketika perusahaan itu menjual penerbitan pertama sahamnya dalam penawaran umum kepada investor.

\section{Underpricing}

Underpricing saham adalah suatu keadaan dimana harga saham yang dioerdagangkan di pasar perdana lebih rendah dibandingkan ketika di pasar sekunder (Sumarso, 2003 dalam Syahputra, 2008). Menurut (Kunz dan Aggarwal 1994 dalam Yasa, 2008) underpricing adalah suatu keadaan dimana harga saham pada saat penawaran perdana lebih rendah dibandingkan dengan ketika diperdagangkan di pasar sekunder. Underpricing saham juga dapat didefinisikan sebagai suatu keadaan dimana efek yang dijual di bawah nilai likuidasinya atau nilai pasar yang seharusnya diterima oleh pemegang saham (Ang, 1997 dalam Retnowati 2013).

\section{Reputasi Underwriter}

Underwriter menurut Undang-Undang Pasar Modal No. 8 tahun 1995 adalah pihak yang membuat kontrak dengan Emiten untuk melakukan Penawaran Umum bagi kepentingan Emiten dengan atau tanpa kewajiban untuk membeli sisa Efek yang tidak terjual. Underwriter merupakan perusahaan swasta atau BUMN (pihak luar) yang menjembatani kepentingan emiten dan investor yakni menjadi penanggung jawab atas terjualnya efek emiten kepada investor. Masalah penetapan harga saham yang ditawarkan kepada calon pembeli merupakan pekerjaan yang tidak mudah karena rentannya kesalahan kecil yang terjadi saat IPO dapat menyebabkan kegagalan IPO. Harga jual yang terlalu mahal akan menyebabkan sekuritas tidak laku. Sebaliknya, harga yang terlalu murah akan menyebabkan perusahaan mengalami opportunity loss.

\section{Persentase Saham Yang Ditawarkan Ke Publik}

(Nurhidayati dan Indriantono,1998 dalam Maya, 2013) menyatakan persentase saham yang ditawarkan ke publik menunjukkan berapa besar bagian dari modal disetor yang akan dimiliki oleh publik dan digunakan sebagai proksi terhadap faktor ketidakpastian yang akan diterima oleh penjamin emisi dan investor. Proposi dari saham yang ditahan dari pemegang saham lama dapat menunjukan aliran informasi dari saham emiten ke calon investor. Semakin besar proposi saham yang dipegang oleh pemegang saham lama semakin banyak informasi privat yang dimiliki oleh pemegang saham lama.

\section{Penggunaan Dana IPO Untuk Investasi}

Investor pada umumnya lebih berminat pada perusahaan dengan tujuan IPO nya untuk investasi. Menurut (Kim,1993 dalam Aini,2013) dana dari IPO yang digunakan oleh perusahaan sebagai modal baru dapat meningkatkan nilai perusahaan melalui peningkatan kapasitas produksi, disamping itu juga dapat menunjukkan komitmen perusahaan terhadap rencana ekspansi yang mungkin merefleksikan pandangan optimis pemilik (investor) terhadap perusahaan.

\section{Kerangka Konseptual}




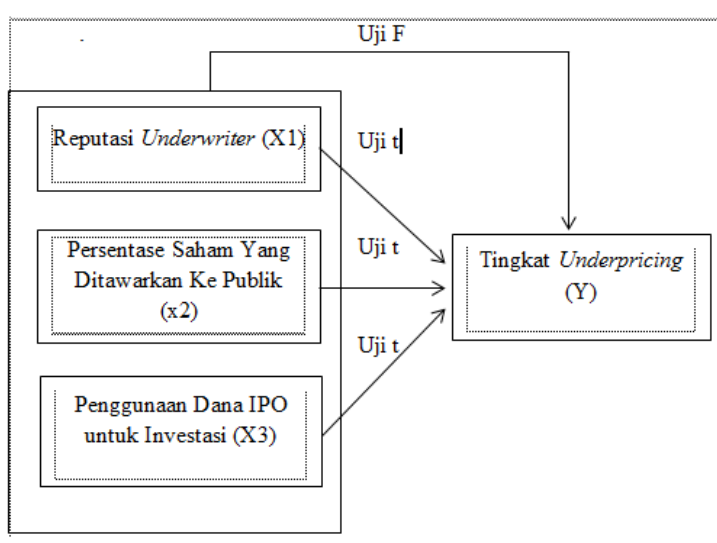

Gambar 1

\section{Perumusan Hipotesis}

H1 :Reputasi Underwriter berpengaruh terhadap tingkat underpricing.

H2 :Persentase penawaran kepada publik berpengaruh terhadap tingkat Underpricing.

H3 :Dana IPO yang Digunakan Untuk Investasi berpengaruh Terhadap Underpricing.

H4 :Reputasi Underwriter, Persentase Saham yang di tawarkan ke publik, dan

Penggunaan dana IPO untuk investasi berpengaruh terhadap Underpricing.

\section{METODE PENELITIAN}

\section{Populai Dan Sampel}

Populasi dalam penelitian ini adalah seluruh perusahaan yang mendaftarkan saham syariah di bursa efek Indonesia periode 2013-2016 yaitu sebanyak 342 perusahaan. Sedangkan sampel dalam penelitian ini berjumlah 33 dengan metode pengambilan sampel menggunakan purposive sampling. Kriteria populasi yang ditetapkan dalam penelitian ini adalah sebagai berikut:

1. Perusahaan yang melakukan Initial Publik Offering (IPO) tahun 2013-2016.

2. Perusahaan yang mengalami underpricing

\section{Jenis Dan Sumber Data}

Jenis data yang diambil peneliti dalam penelitian ini berdasarkan dengan kelompok jenis data yaitu: Jika dilihat berdasarkan cara perolehan data ini merupakan data sekunder dikarenakan penelitian ini menggunakan data dari laporan keuangan dari perusahaan yang bersangkutan.

\section{Operasional Variabel}

Tabel 2

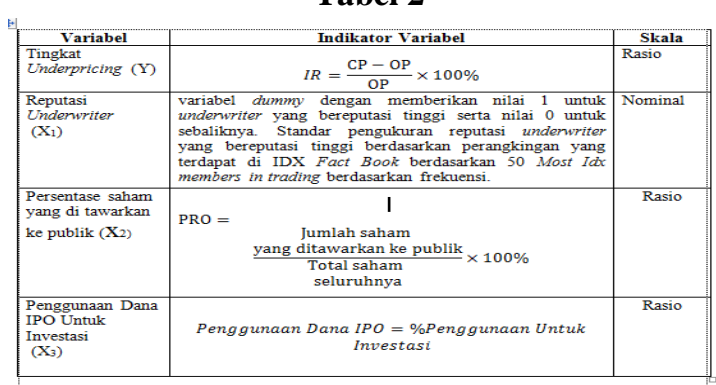

Uji Regresi Linier Bergada

Adapun formulasi persamaan regresi berganda sebagai berikut:

\begin{tabular}{cl}
\multicolumn{1}{l}{$\mathbf{Y}=\mathbf{a}+\mathbf{b}_{\mathbf{1}} \mathbf{X}_{\mathbf{1}}+\mathbf{b}_{\mathbf{2}} \mathbf{X}_{\mathbf{2}}+\mathbf{b}_{\mathbf{3}} \mathbf{X}_{\mathbf{3}}+\mathbf{e}$} \\
Keterangan : \\
$\mathrm{Y} \quad:$ Underpricing \\
$\mathrm{a}$ & $:$ Konstanta \\
$\mathrm{b}$ & $:$ Koefisien Regresi \\
$\mathrm{X}_{1}$ & $:$ Reputasi Underwriter \\
$\mathrm{X}_{2}$ & $:$ Persentase saham yang di \\
& tawarkan ke publik \\
$\mathrm{X}_{3}$ & $:$ Penggunaan dana IPO \\
untuk investasi \\
$\mathrm{e}$
\end{tabular}

\section{HASIL DAN PEMBAHASAN}

\section{Uji Asumsi Klasik}

\section{a. Uji Normalitas}

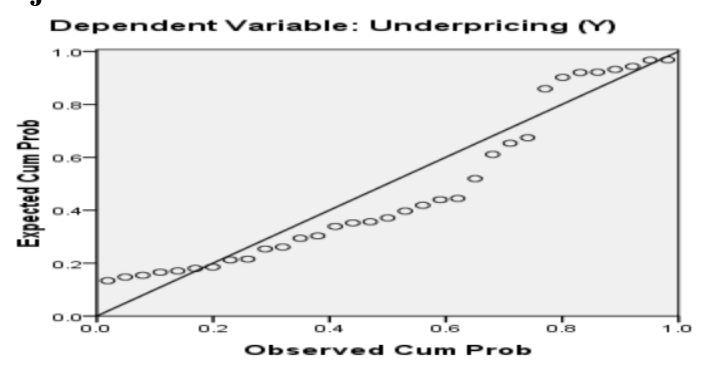

Gambar 2

Berdasarkan hasil output grafik normal probability plot menunjukkan penyebaran titik berada disekitar garis diagonal, oleh karena itu dapat dikatakan bahwa model regresi berdistribusi normal.

\section{b. Uji Autokorelasi}

Tabel 3 


\begin{tabular}{|c|c|c|c|c|c|}
\hline Model & $\mathrm{R}$ & R Square & $\begin{array}{l}\text { Adjusted R } \\
\text { Square }\end{array}$ & $\begin{array}{l}\text { Std. Error of } \\
\text { the Estimate }\end{array}$ & $\begin{array}{l}\text { Durbin- } \\
\text { Watson }\end{array}$ \\
\hline 1 & $.331^{\mathrm{a}}$ & .110 & .018 & 20.39937 & 2.637 \\
\hline \multicolumn{6}{|c|}{$\begin{array}{l}\text { a. Predictors: (Constant), Penggunaan Dana IPO untuk Investasi (X3), } \\
\text { Persentase Saham yang di tawarkan ke publik (X2), Underwriter (X1) }\end{array}$} \\
\hline
\end{tabular}

Berdasarkan hasil perhitungan tabel diatas nilai DW sebesar 2,637 dengan jumlah $\mathrm{k}$ (variabel independen) sebanyak 2 dan jumlah sampel sebanyak 33. Dalam tabel Durbin Warson menunjukkan nilai dL (batas bawah) $=1,257$ dan $\mathrm{dU}$ (batas atas) $=1,651$, sehingga nilai D-W 2,637 lebih besar dari dU (batas atas) dan kurang dari (4dU) $4-1,651=2,349$. Sehingga dapat disimpulkan bahwa tidak ada autokorelasi dalam model regresi.

\section{c. Uji Multikolinieritas}

dapat kita lihat hasil VIF untuk reputasi underwriter sebesar 1,106 sedangkan untuk persentase saham yang ditawarkan ke publik sebesar 1,050 dan penggunaan dana IPO untuk investasi sebesar 1,152 . Karena nilai VIF kurang dari 10 dan tolerance value diatas 0,10 maka dapat disimpulkan bahwa pada model regresi tidak di temukan masalah Multikolinearitas

\section{d. Uji Heteroskedatisitas}

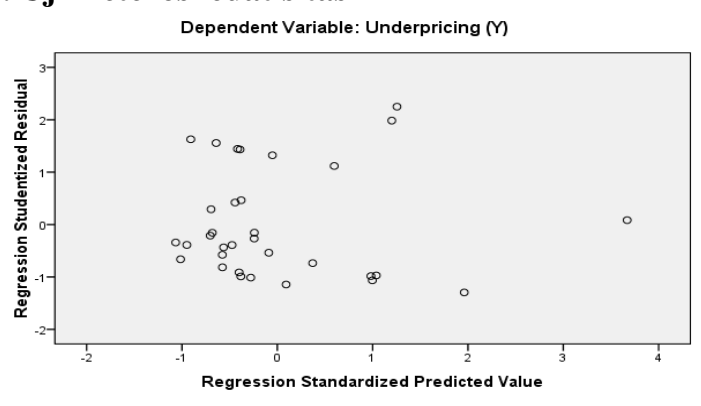

Gambar 3

Berdasarkan hasil uji heteroskedastisitas pada gambar Grafik scatter plot menunjukkan bahwa titik-titik menyebar secara acak serta tersebar baik di atas maupun di bawah angka 0 pada sumbu Y. Hal ini dapat disimpulkan bahwa tidak terjadi heteroskedastisitas pada model regreso, sehingga model regresi layak dipakai untuk memprediksi tingkat Underpricing berdasarkan masukan variabel independen reputasi underwriter, persentase saham yang ditawarkan ke publik dan penggunaan dana IPO untuk investasi.

\section{Uji Linier Berganda}

Tabel 3

\begin{tabular}{|c|c|c|c|c|c|c|}
\hline \multirow{2}{*}{\multicolumn{2}{|c|}{ Model }} & \multicolumn{2}{|c|}{$\begin{array}{l}\text { Unstandardized } \\
\text { Coefficients }\end{array}$} & \multirow{2}{*}{\begin{tabular}{|c|}
$\begin{array}{c}\text { Standardized } \\
\text { Coefficients }\end{array}$ \\
Beta \\
\end{tabular}} & \multirow[b]{2}{*}{$\mathrm{t}$} & \multirow[b]{2}{*}{ Sig. } \\
\hline & & B & Std. Error & & & \\
\hline \multirow[t]{4}{*}{1} & (Constant) & 23.813 & 13.152 & & 1.811 & .081 \\
\hline & Underwriter (X1) & -12.904 & 12.989 & -.183 & -.993 & .329 \\
\hline & $\begin{array}{l}\text { Persentase Saham yang } \\
\text { di tawarkan ke publik } \\
\text { (X2) }\end{array}$ & .437 & .260 & .301 & 1.679 & .104 \\
\hline & $\begin{array}{l}\text { Penggunaan Dana IPO } \\
\text { untuk Investasi (X3) }\end{array}$ & .060 & .125 & .090 & .478 & .636 \\
\hline
\end{tabular}

Berdasarkan hasil perhitungan dari uji regresi linier berganda diperoleh nilai konstanta (a) dari model regresi $=23,813$ dan koofisien regresi $\left(b_{1}\right)$ dari setiap variabel-variabel independen diperoleh $b_{1}=-12,904, b_{2}=0,437$ dan $b_{3}=0,60$. Berdasarkan nilai konstanta dan koefisien regresi tersebut, maka hubungan antara variabel-variabel independen dengan variabel dependen dalam model regrsi dapat dirumuskan sebagai berikut :

$$
\mathrm{Y}=23,813-12,904 \mathrm{X}_{1}+0,437 \mathrm{X}_{2}+0,60 \mathrm{X}_{3}
$$

Dari persamaan regresi diatas dapat dijadikan sebagai berikut :

1. Nilai konstanta (a) adalah 23,813 , dapat diartikan jika reputasi underwriter, persentase saham yang ditawarkan ke publik dan penggunaan dana IPO untuk investasi nilainya konstan, maka tingkat Underpricingnya adalah sebesar 23,813\%

2. Nilai koofisien regresi variabel reputasi underwriter $\left(\mathrm{b}_{1}\right)$ bernilai negative, yaitu 12,904, maka dapat diartikan bahwa setiap peningkatan reputasi underwriter sebesar $1 \%$ maka akan menurunkan tingkat Underpricing sebesar 12,904 begitu juga sebaliknya dengan asumsi variabel independen lainnya tetap.

3. Nilai koofisien regresi variabel persentase saham yang di tawarkan ke publik $\left(b_{3}\right)$ bernilai positif yaitu sebesar 0,437 , maka dapat diartikan bahwa setiap peningkatan persentse saham yang ditawarkan ke publik sebesar $1 \%$ maka akan meningkatkan tingkat Underpricing sebesar 0,437 begitu juga sebaliknya dengan asumsi variabel independen lainnya tetap.

4. Nilai koofisien regresi variabel penggunaan dana IPO untuk investasi $\left(b_{4}\right)$ bernilai positif yaitu sebesar 0,60 , maka dapat diartikan bahwa setiap peningkatan persentse saham yang ditawarkan ke publik sebesar $1 \%$ maka akan meningkat tingkat Underpricing sebesar 0,060 begitu 
juga sebaliknya dengan asumsi variabel independen lainnya tetap.

\section{Pembahasan \\ Pengaruh Reputasi Underwriter terhadap Underpricing.}

Berdasarkan hasil analisis statistik dalam penelitian ini yang menunjukkan bahwa variabel Reputasi underwriter, tidak berpengaruh terhadap tingkat Underpricing saham syariah pada perusahaan yang terdaftar di BEI tahun 2013-2016. Hal ini ditunjukkan oleh tabel coeffisien diperoleh nilai $\mathrm{t}_{\text {hitung }}=-0,993$ yang artinya $\mathrm{t}_{\text {hitung }}<\mathrm{t}_{\text {tabel }} \quad(-$ $0,993<2,042)$ dengan signifikansi $0,329>0,05$ maka $\mathrm{H}_{1}$ ditolak artinya Artinya Reputasi Underwriter tidak berpengaruh terhadap Underpricing saham syariah.

Pengujian pada penelitian ini menunjukkan reputasi underwriter tidak berpengaruh terhadap Underpricing saham pada perusahaan yang melaksanakan IPO 2007-2011. Tidak berpengaruhnya reputasi underwriter terhadap Underpricing disebabkan karena penggunaan underwriter yang bereputasi baik oleh emiten tidak memberikan sinyal bagi investor untuk memperkirakan nilai yang pantas (sesungguhnya) bagi perusahaan IPO, hal ini didukung oleh alasan hasil penelitian Triani (2006).

Reputasi Underwriter tidak berpengaruh di karenakan investor tidak melihat dari seberapa bagus atau baiknya Underwriter yang digunakan melainkan investor melihat dari aspek-aspek lain dari suatu perusahaan seperti melihat harga penawaran perdana yang relatif rendah. Investor menginginkan adanya Initial Return yang tinggi sehingga mereka mengganggap tidak masalah apabila reputasi underwriter yang digunakan tidak bereputasi baik pada saat Initial Publik Offering (IPO). Bahkan semakin bagus reputasi underwriter digunakan maka semakin tinggi tingkat Underpricing dikarenakan underwriter yang sudah bereputasi baik tidak mau menanggung resiko apabila saham perusahaan tidak laku terjual. Sehingga underwriter menekankan harga penawaran perdanan yang relatif kecil, semakin kecil harga penawaran perdana maka semakin tinggi tingkat Underpricing. Salah satu perusahaan yang menggunakan Reputasi underwriter yang bereputasi baik adalah PT Bali Towerindo Tbk yang menggunakan jasa underwriter RBH OSK Sekurities Indonesia yang merupakan salah satu penjamin emisi yang termasuk dalam 50 Most idx aktive berdasarkan frekuensi, namun tetap terjadi underpricing pada saat penawaran perdana yaitu sebesar $50 \%$.

Hal ini hal ini didukung oleh hasil penelitian Hartono (2005) yang menyatakan bahwa reputasi underwriter kurang reliable mewakili konstruk sinyal positif. Sehingga reputasi underwriter mempengaruhi keputusan para investor dalam investasi saham IPO. Namun penelitian ini bertentangan dengan penelitian yang dilakukan oleh Asrini (2016) yang menyatakan reputasi underwriter berpengaruh signifikan negatif terhadap Underpricing saham.

\section{Pengaruh Persentase saham yang ditawarkan ke publik terhadap Underpricing.}

Berdasarkan hasil uji statistik $\mathrm{t}$ dapat diketahui bahwa variabel persentase saham yang di tawarkan ke publik tidak berpengaruh terhadap tingkat Underpricing saham syariah yang terdaftar di BEI tahun 2013-2016. Hal ini dapat dilihat dari hasil $\mathrm{t}$ hitung lebih kecil dari pada t tabel yaitu $(1,679<$ 2,042) dengan signifikansi 0,104>0,05.

Persentase penawaran kepada publik yang menggambarkan porsi kepemilikan saham yang dikuasai oleh publik menunjukkan tidak adanya pengaruh yang signifikan terhadap tingkat Underpricing. Menurut ownership dan control theory manajemen perusahaan berusaha untuk mempertahankan kendali perusahaan setelah melakukan IPO, dan hal tersebut tidak dipengaruhi oleh jumlah kepemilikan yang dilepas perusahan kepada publik.

Tidak berpengaruhnya Persentase Saham yang ditawarkan ke Publik terhadap Underpricing disebabkan bahwa besar kecilnya saham yang ditawarkan kepada publik belum bisa menjelaskan prospek perusahaan di masa akan datang. Meskipun proporsi saham yang ditawarkan kepada publik itu tinggi, belum tentu mampu menyatakan privat informasi perusahaan tidak ada dan belum mampu menentukan nilai ketidakpastian return dimasa mendatang. Hal ini juga mengindikasikan bahwa investor akan melakukan pembelian saham yang ditawarkan ke publik bukan berorientasi pada jumlah lembar saham yang ditawarkan tetapi berapa nilai penawaran saham tersebut (Baskoro dan Moin, 2011). Menurut Gu (2003) ketika banyak perusahaan yang masuk bursa, investor cenderung memilih penawaran umum yang 
dilakukan perusahaan milik negara karena perusahaan milik negara bergerak disektor industri yang strategis.

Para investor berpandangan bahwa besar kecilnya persentase saham yang ditawarkan ke publik tidak berpengaruh karena investor cenderung melihat kepada tinggi rendahnya harga saham per lembar yang ditawarkan emiten diharapkan dapat menentukan besar kecilnya keuntungan kedepannya, dimana akan mempengaruhi tingkat penawaran dan permintaan ketika di pasar sekunder. Seperti halnya PT Bali Towerindo Tbk yang persentase sahmnya mencapai $87,16 \%$ pada saat penawaran perdana namun tetap terjadi underpricing, ini membuktikan underpricing tidak dipengaruhi oleh besar kecilnya saham yang ditawarkan ke publik.

Hasil penelitian ini sesuai dengan penelitian yang di lakukan oleh penelitian Baskoro dan Moin (2011), Yasa (2008) serta penelitian Yustisia dan Roza (2012), Gabriels (2013) dam Emilia, dkk (2008) bahwa Persentase Saham yang ditawarkan ke Publik tidak berpengaruh signifikan terhadap Underpricing. Namun tidak sejalan dengan penelitian Beatty (1989) dan penelitian Daljono (2000) bahwa Persentase Saham yang ditawarkan ke Publik mempunyai pengaruh negatif terhadap Underpricing.

\section{Pengaruh penggunaan dana IPO untuk investasi terhadap Underpricing.}

Berdasarkan hasil uji statistik t dapat diketahui bahwa variabel penggunaan dana IPO untuk investasi tidak berpengaruh terhadap tingkat Underpricing saham syariah yang terdaftar di BEI tahun 2013-2016. Hal ini dapat dilihat dari tabel coeffisien diperoleh nilai $\mathrm{t}_{\text {hitung }}=0,478$ yang artinya $t_{\text {hitung }}<\mathrm{t}_{\text {tabel }}(0,478<2,042)$ dengan signifikansi $0,636>0,05$ maka $\mathrm{H}_{3}$ ditolak Artinya penggunaan dana IPO untuk investasi tidak berpengaruh terhadap Underpricing saham syariah.

Informasi menegenai penggunaan dana IPO ternyata tidak menjadi sinyal yang positif bagi perusahaan. Karena investor percaya penggunaan dana hasil IPO digunakan untuk sesuatu hal yang baik oleh perusahaan. Hal ini dapat dilihat dari rata-rata statistik deskriptif untuk penggunaan dana IPO untuk investasi sebesar 32,41 artinya hanya sekitas 32,41\% penggunaan Dana Hasil IPO yang digunakan untuk investasi. Hal ini menunjukan rendahnya penggunaan dana hasil
IPO untuk investasi. Perusahaan yang telah memiliki nama di masyarakat, akan lebih dipercaya oleh calon investor sehingga calon investor yakin bahwa perusahaan akan menggunakan dana hasil IPO secara cermat. Perusahaan akan mempertaruhkan nama baiknya bila perusahaan tidak mampu menggunakan dana IPO secara baik. PT Capitol Nusantara Indonesia yang menggunakan $100 \%$ dana hasil IPO untuk investasi namun tetap terjadi underpricing pada saat penawaran perdananya.

Penelitian ini sejalan dengan penelitian yang dilakukan oleh Aini (2014) dan asrini (2016), kartika (2017) yang menyatakan bahwa penggunaan dana IPO untuk investasi tidak berpengaruh terhadap tingkat Underpricing dan bertentangan dengan penelitian yang dilakukan oleh kristiantari (2013).

Pengaruh Reputasi Underwriter, Persentase saham yang ditawarkan ke publik dan penggunaan dana IPO untuk investasi terhadap Underpricing.

Berdasarkan hasil analisis statistik dalam penelitian ini yang menunjukkan bahwa variabel Reputasi underwriter, persentase saham yang ditawarkan ke publik dan penggunaan dana IPO untuk investasi tidak berpengaruh secara simultan terhadap tingkat Underpricing saham syariah pada perusahaan yang terdaftar di BEI tahun 2013-2016. Hal ini ditunjukkan oleh hasil nilai Fhitung < F tabel yakni $1,192<2,93$ dan nilai signifikan sebesar $0.330>0.05$.

Berdasarkan hasil penelitian dengan menggunakan koefisien determinasi $\left(\mathrm{R}^{\wedge} 2\right)$, diperoleh nilai $\mathrm{R}^{\wedge} 2$ sebesar 0,110 atau $11 \%$ variasi variabel independen yaitu reputasi underwriter, persentase saham yang di tawarkan ke publik dan penggunaan dana IPO untuk investasi terhadap tingkat Underpricing saham syariah. Nilai ini menunjukkan bahwa ketiga variabel independen berpengaruh terhadap tingkat Underpricing sebesar $11 \%$ dan sisanya sebesar $89 \%$ dipengaruhi oleh faktor lain yang tidak diteliti dalam penelitian ini. Adapun nilai $\mathrm{R}$ yang diperoleh sebesar 0,331 atau $33,1 \%$.

Dari hasil tolak ukur yang digunakan dalam penelitian ini menunnjukkan bahwa masih ada variabel-variabel lain yang dapat mempengaruhi tingkat Underpricing. Seperti dalam penelitian Haspari (2012) yang menggunakan Current Rasio sebagai salah satu faktor yang mempengaruhi 
tingkat Underpricing saham syariah Penelitian lainnya adalah penelitian Pahlepi (2014) yang menggunakan variabel Earning Per Share (EPS) sebagai variabel independen yang tidak di teliti dalam penelitian ini.

\section{KESIMPULAN DAN SARAN}

\section{Kesimpulan}

Berdasarkan pengujian dan hasil penelitian yang telah dilakukan mengenai pengaruh reputasi underwriter, persentase saham yang ditawarkan ke publik dan penggunaan dana IPO untuk investasi terhadap tingkat underpricing saham syariah, maka penulis dapat mengambil kesimpulan sebagai berikut:

1. Hasil pengujian hipotesis diperoleh bahwa variabel Reputasi underwriter tidak berpengaruh signifikan terhadap tingkat underpricing saham syariah pada perusahaan yang IPO di BEI tahun 20132016. Penggunaan underwriter yang bereputasi baik tidak menjamin berkurangnya underpricing yang terjadi ketika perusahaan melakukan penawaran perdana (IPO).

2. Hasil pengujian hipotesi kedua diperoleh bahwa variabel persentase saham yang ditawarkan ke publik tidak berpengaruh signifikan terhadap tingkat underpricing saham syariah pada perusahaan yang IPO di BEI tahun 2013-2016. Besarnya persentase saham yang ditawarkan ke publik tidak menggambarkan besarnya keuntungan (return) di masa mendatang, pada saat penawaran perdana investor cenderung melihat harga penawaran perdananya bukan melihat besarnya persentase saham yang ditawarkan.

3. Hasil pengujian hipotesis ketiga menunjukkan bahwa penggunaan dana IPO untuk investasi tidak berpengaruh signifikan terhadap tingkat underpricing saham syariah pada perusahaan yang IPO di BEI tahun 2013-2016. Investor tidak terlalu memperhatikan rencana penggunaan dana IPO untuk investasi pada saat membeli saham perdana, karena investor percaya bahwa perusahaan pasti menggunakan dana hasil IPO untuk investasi agar investor tertarik untuk membeli saham pada penawaran perdananya.

4. Pengujian hipotesis dengan uji $F$ dilakukan dengan membandingkan antara Fhitung dengan Ftabel, dan nilai signifikansinya menunjukkan bahwa secara simultan variabel Reputasi underwriter (X1), Persentase saham yang ditawarkan ke publik (X2), dan penggunaan dana IPO untuk investasi (X3) tidak berpengaruh secara signifikan terhadap tigkat underpricing saham syariah (Y) pada perusahaan yang IPO di BEI tahun 2013-2016.

\section{Saran}

Melihat kesimpulan sebelumnya terdapat beberapa saran dan pertimbangan yang disajikan dalam penelitian ini antara lain:

1. Periode penelitian selanjutnya sebaiknya lebih dari 4 tahun karena periode yang lebih panjang diharapkan dapat memungkinkan tingkat kebenaran $100 \%$ sehingga mencerminkan kondisi perusahaan yang sebenarnya.

2. Untuk peneliti selanjutnya dapat mencoba menggunakan variabel-variabel lainnya baik bersifat internal perusahaan ataupun dari eksternal perusahaan, keuangan maupun non-keuangan yang mungkin dapat mempengaruhi tingkat underpricing atau initial return. Peneliti selanjutnya bisa juga meneruskan penelitian ini dengan menggunakan variabel kurs, inflasi, dan BI Rate dikarenakan belum terlalu banyak penelitian yang menggunakan ketiga variabel tersebut dalam penelitian mengenai pengaruh terhadap underpricing, khususnya dua variabel inflasi dan BI Rate karena penulis sendiri dalam penelitian ini belum menemukan refrensi jurnal-jurnal yang menyangkut kedua variabel tersebut dalam mempengaruhi tingkat underpricing. Serta untuk peneliti selanjutnya dapat meneliti tentang overpricing.

3. Untuk peneliti selanjutnya dapat menggunakan data perusahaan yang terdaftar di BEI tidak hanya terbatas pada yang syariah. Peneliti selanjutnya 
juga dapat menggunakan data perusahaan yang terdaftar pada sektorsektor industri yang terdaftar di BEI atau dapat menggunakan data perusahaan yang terdaftar pada ISSI atau JII.

\section{DAFTAR PUSTAKA}

Aini, Shoviyah Nur. 2013. Faktor-Faktor Yang Mempengaruhi Underpricing Saham Pada Perusahaan IPO di BEImPeriode 2007-2011. Jurnal IlmiahmManajemen. Vol 1 No 1. Januari 2013.

Boubaker and Mezhoud. 2011. Determinants of the Components of IPO Initial Returns: Paris Stock Exchange. International Journal of Accounting and Financial Reporting. Vol 1. No 1.

Brealey, Richard, dkk, 2007, Dasar-Dasar manajemen keuangan perusahaan, Jakarta: Erlangga, Jilid 1

Handayani, S.R., 2008, Analisis Faktor-Faktor yang Mempengaruhi Underpricing pada Penawaran Umum Perdana (Studi Kasus pada Perusahaan Keuangan yang Go Public di Bursa Efek Jakarta Tahun 2000-2006), Tesis Tidak Dipublikasikan, Universitas Diponegoro: Semarang.

Ljungqvist, Alexander. 2006. IPO Underpricing, Handbook of Corporate Finance: Empirical Corporate Finance, Volume A, (Handbooks in Finance Series, Elsevier/North Holland), Chapter 7

Maya. 2013. Pengaruh Kondisi Pasar, Persentase Saham yang Ditawarkan, Financial Leverage, dan Profitabilitas terhadap Underpricing Saham yang IPO di BEI periode 2007-2011. Universitas Negeri Padang.

Sandhiaji, Bram Nugroho. 2004. Analisis FaktorFaktor yang Mempengaruhi Tingkat Underpricing pada Penawaran Umum Perdana (IPO) Perioe Tahun 1996-2002 (Studi Kasus Pada Perusahaan Manufaktur Yang Go Publik di Bursa Efek Jakarta Tahun 1996-2002) $)^{\text {ee }}$. Tesis tidak diterbitkan. Semarang: Magister Manajemen, Universitas Diponegoro.

Suyatmin dan Sujadi. 2006. Faktor-Faktor Yang Mempengaruhi Underpricing Pada Penawaran Umum Perdana di Bursa
Efek Jakarta . Benefit. Vol 10 No 1 Juni 2006.

Trianingsih, Sri. 2005. Faktor-Faktor yang Mempengaruhi Tingkat Underpricing pada Penawaran Perdana Di BEJ. Jurnal Akuntansi dan Keuangan. Hal: 195-210. UMS

Yasa, G.W., 2008, Penyebab Underpricing pada Penawaran Saham Perdana, Jurnal Akuntansi Bisnis, Vol.3, No.2, Juli: 145157.

Yong, O. 2009. Significance of Investor Demand, Firm Size, Offer Type and Offer Size on The Initial Premium, First Day Price Spread and Flipping Activity of Malaysian IPOs."Prosiding Perkem IV". Jilid 1. 2009. 395-412. 
